\title{
Triggering of Suicidal Erythrocyte Death Following Boswellic Acid Exposure
}

\author{
Salvatrice Calabrò ${ }^{\mathrm{a}, \mathrm{b}}$ Kousi Alzoubia ${ }^{\mathrm{a}}$ Caterina Faggio ${ }^{\mathrm{b}}$ Stefan Laufer ${ }^{\mathrm{c}}$ Florian Lang ${ }^{\mathrm{a}}$

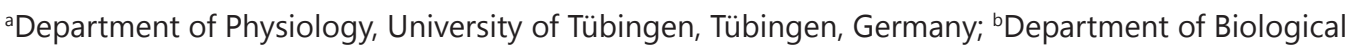 \\ and Environmental Sciences, University of Messina, Messina, Italy; 'Department of Pharmaceutical \\ Chemistry, University of Tübingen, Tübingen, Germany
}

\section{Key Words}

Phosphatidylserine $\cdot$ Cell volume $・$ p38 kinase $・$ Skepinone $・$ SB203580 • Eryptosis

\begin{abstract}
Background/Aims: The antinflammatory natural product boswellic acid is effective against cancer at least in part by inducing tumor cell apoptosis. Similar to apoptosis of nucleated cells erythrocytes may enter eryptosis, a suicidal death characterized by cell shrinkage and cell membrane scrambling with phosphatidylserine translocation to the erythrocyte surface. Stimulators of eryptosis include oxidative stress, increase of cytosolic $\mathrm{Ca}^{2+}$-activity $\left(\left[\mathrm{Ca}^{2+}\right]_{i}\right)$, energy depletion, ceramide formation and p38 kinase activation. The present study tested, whether and how boswellic acid induces eryptosis. Methods: Phosphatidylserine exposure at the cell surface was estimated from annexin $\mathrm{V}$ binding, cell volume from forward scatter, hemolysis from hemoglobin release, $\left[\mathrm{Ca}^{2+}\right]_{\mathrm{i}}$ from Fluo3-fluorescence, ceramide abundance utilizing specific antibodies, reactive oxygen species (ROS) from 2', 7'-dichlorodihydrofluorescein diacetate (DCFDA) fluorescence, and cytosolic ATP concentration utilizing a luciferinluciferase assay kit. Results: A 24 hours exposure of human erythrocytes to boswellic acid $(5 \mu \mathrm{g} / \mathrm{ml})$ significantly increased the percentage of annexin-V-binding cells (to $9.3 \pm 0.9 \%$ ) and significantly decreased forward scatter. Boswellic acid did not significantly modify $\left[\mathrm{Ca}^{2+}\right]_{\mathrm{i}}$ cytosolic ATP, ROS, or ceramide abundance. The effect of boswellic acid on annexin-V-binding was significantly blunted, but not abolished by p38 kinase inhibitors skepinone $(2 \mu \mathrm{M})$ and SB203580 $(2 \mu \mathrm{M})$. Conclusions: Boswellic acid stimulates cell shrinkage and phospholipid scrambling of the erythrocyte cell membrane, an effect in part dependent on p38 protein kinase activity.
\end{abstract}




\section{Cellular Physiology Cell Physiol Biochem 2015;37:131-142

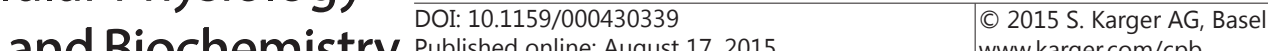 and Biochemistry Published online: August 17, $2015 \quad$ www.karger.com/cpb \\ Calabrò/Alzoubi/Faggio/Laufer/Lang: Boswellic Acid-Induced Eryptosis}

\section{Introduction}

Boswellic acid, a component of Boswellia serrata extracts [1,2] is a powerful modulator of the immune system [1,2] and has been shown to counteract inflammation $[1,3-8]$ and malignancy [9-17]. The anticancer effect of boswellic acid and its derivatives is at least partially due to stimulation of suicidal tumor cell death or apoptosis [15, 18-28]. Mechanisms involved in boswellic acid induced apoptosis include downregulation of PI3K/Akt and ERK pathways [29-31], modulation of the Wnt/ $\beta$-catenin signaling pathway [32], influence on p53/PUMA/ Bax [33], topoisomerase I \& II down-regulation [10, 11, 34], inhibition of mammalian target of rapamycin [35], down-regulation of NF- $\mathrm{B}$ [36-39], altered gene expression [14, 39-44], mitochondrial depolarization [45], and caspase activation [23, 46-48].

Similar to apoptosis of nucleated cells, erythrocytes may enter eryptosis, the suicidal death of erythrocytes characterized by cell shrinkage [49] and cell membrane scrambling with phosphatidylserine translocation to the cell surface [50]. Cellular mechanisms triggering eryptosis include oxidative stress [50], $\mathrm{Ca}^{2+}$ entry with increase of cytosolic $\mathrm{Ca}^{2+}$ activity $\left(\left[\mathrm{Ca}^{2+}\right]_{\mathrm{i}}\right)[50]$, ceramide [51], energy depletion [50], activated caspases [50, 52, 53], stimulated activity of casein kinase $1 \alpha$, Janus-activated kinase JAK3, protein kinase C, and p38 kinase [50], as well as impaired activity of AMP activated kinase AMPK, cGMP-dependent protein kinase, PAK2 kinase and sorafenib/sunitinib sensitive kinases [50]. Eryptosis is further triggered by a wide variety of xenobiotics [50, 54-82].

The present study explored, whether and how boswellic acid triggers eryptosis. To this end, human erythrocytes from healthy volunteers were treated with boswellic acid and phosphatidylserine surface abundance and cell volume determined by flow cytometry.

\section{Materials and Methods}

\section{Erythrocytes, solutions and chemicals}

Fresh Li-Heparin-anticoagulated blood samples were kindly provided by the blood bank of the University of Tübingen. The study is approved by the ethics committee of the University of Tübingen (184/2003 V). The blood was centrifuged at $120 \mathrm{~g}$ for $20 \mathrm{~min}$ at $21^{\circ} \mathrm{C}$ and the platelets and leukocytes-containing supernatant was disposed. Erythrocytes were incubated in vitro at a hematocrit of $0.4 \%$ in Ringer solution containing (in $\mathrm{mM}$ ) $125 \mathrm{NaCl}, 5 \mathrm{KCl}, 1 \mathrm{MgSO}_{4^{\prime}}, 32 \mathrm{~N}$-2-hydroxyethylpiperazine-N-2-ethanesulfonic acid (HEPES), 5 glucose, $1 \mathrm{CaCl}_{2}$; $\mathrm{pH} 7.4$ at $37^{\circ} \mathrm{C}$ for $24 \mathrm{~h}$. Where indicated, erythrocytes were exposed to boswellic acid (Sigma Aldrich, Hamburg, Germany), skepinone [83] or SB203580 (Sigma Aldrich, Hamburg, Germany) at the indicated concentrations.

\section{Annexin-V-binding and forward scatter}

After incubation under the respective experimental condition, $150 \mu \mathrm{l}$ cell suspension was washed in Ringer solution containing $5 \mathrm{mM} \mathrm{CaCl}_{2}$ and then stained with Annexin-V-FITC (1:200 dilution; ImmunoTools, Friesoythe, Germany) in this solution at $37^{\circ} \mathrm{C}$ for $20 \mathrm{~min}$ under protection from light. The annexin $V$ abundance at the erythrocyte surface was subsequently determined on a FACS Calibur (BD, Heidelberg, Germany). A dot plot of forward scatter (FSC) vs. side scatter (SSC) was set to linear scale for both parameters. The threshold of forward scatter was set at the default value of " 52 ".

Measurement of hemolysis

For the determination of hemolysis, the samples were centrifuged $(3 \mathrm{~min}$ at $1600 \mathrm{rpm}$, room temperature) after incubation under the respective experimental conditions and the supernatants were harvested. As a measure of hemolysis, the hemoglobin ( $\mathrm{Hb}$ ) concentration of the supernatant was determined photometrically at $405 \mathrm{~nm}$. The absorption of the supernatant of erythrocytes lysed in distilled water was defined as $100 \%$ hemolysis.

Intracellular $\mathrm{Ca}^{2+}$

After incubation, erythrocytes were washed in Ringer solution and then loaded with Fluo-3/AM (Biotium, Hayward, USA) in Ringer solution containing $5 \mathrm{mM} \mathrm{CaCl}_{2}$ and $5 \mu \mathrm{M}$ Fluo-3/AM. The cells were incubated at $37^{\circ} \mathrm{C}$ for $30 \mathrm{~min}$ and washed twice in Ringer solution containing $5 \mathrm{mM} \mathrm{CaCl} 2^{\text {. The Fluo-3/ }}$ 


\section{Cellular Physiology Cell Physiol Biochem 2015;37:131-142 \begin{tabular}{l|l|l}
\hline DOI: 10.1159/000430339 2015 S. Karger AG, Basel & (C)
\end{tabular} \begin{tabular}{l|l|l|l|l|l} 
and Biochemistry Published online: August 17, 2015 & www.karger.com/cpb \\
\cline { 1 - 2 }
\end{tabular} \\ Calabrò/Alzoubi/Faggio/Laufer/Lang: Boswellic Acid-Induced Eryptosis}

AM-loaded erythrocytes were resuspended in $200 \mu \mathrm{l}$ Ringer. Then, $\mathrm{Ca}^{2+}$-dependent fluorescence intensity was measured with an excitation wavelength of $488 \mathrm{~nm}$ and an emission wavelength of $530 \mathrm{~nm}$ on a FACS Calibur.

\section{Determination of ceramide formation}

For the determination of ceramide, a monoclonal antibody-based assay was used. After incubation, cells were stained for 1 hour at $37^{\circ} \mathrm{C}$ with $1 \mu \mathrm{g} / \mathrm{ml}$ anti ceramide antibody (clone MID 15B4, Alexis, Grünberg, Germany) in PBS containing $0.1 \%$ bovine serum albumin (BSA) at a dilution of 1:10. The samples were washed twice with PBS-BSA. Subsequently, the cells were stained for 30 minutes with polyclonal fluorescein isothiocyanate (FITC) conjugated goat anti-mouse IgG and IgM specific antibody (Pharmingen, Hamburg, Germany) diluted 1:50 in PBS-BSA. Unbound secondary antibody was removed by repeated washing with PBS-BSA. The samples were then analyzed by flow cytometric analysis with an excitation wavelength of 488 $\mathrm{nm}$ and an emission wavelength of $530 \mathrm{~nm}$.

Reactive oxygen species (ROS)

Oxidative stress was determined utilizing 2',7'-dichlorodihydrofluorescein diacetate (DCFDA). After incubation, a $100 \mu \mathrm{l}$ suspension of erythrocytes was washed in Ringer solution and then stained with DCFDA (Sigma, Schnelldorf, Germany) in Ringer solution containing DCFDA at a final concentration of 10 $\mu \mathrm{M}$. Erythrocytes were incubated at $37^{\circ} \mathrm{C}$ for $30 \mathrm{~min}$ in the dark and then washed three times in Ringer solution. The DCFDA-loaded erythrocytes were resuspended in $200 \mu$ l Ringer solution, and ROS-dependent fluorescence intensity was measured at an excitation wavelength of $488 \mathrm{~nm}$ and an emission wavelength of $530 \mathrm{~nm}$ on a FACS Calibur (BD).

\section{Determination of intracellular ATP concentration}

For the determination of intracellular erythrocyte ATP, $90 \mu \mathrm{l}$ of erythrocyte pellets were incubated for $24 \mathrm{~h}$ at $37^{\circ} \mathrm{C}$ in Ringer solution with or without boswellic acid ( $5 \mu \mathrm{g} / \mathrm{ml}$ ). All subsequent manipulations were performed at $4^{\circ} \mathrm{C}$ to avoid ATP degradation. Cells were lysed in distilled water, and proteins were precipitated by addition of $\mathrm{HClO}_{4}(5 \%)$. After centrifugation, an aliquot of the supernatant $(400 \mu \mathrm{l})$ was adjusted to $\mathrm{pH} 7.7$ by addition of saturated $\mathrm{KHCO}_{3}$ solution. After dilution of the supernatant, the ATP concentrations of the aliquots were determined utilizing a luciferin-luciferase assay kit (Roche Diagnostics) on a luminometer (Berthold Biolumat LB9500, Bad Wildbad, Germany) according to the manufacturer's protocol. ATP concentrations are expressed in mmol/l cytosol of erythrocytes.

\section{Statistics}

Data are expressed as arithmetic means \pm SEM. As indicated in the figure legends, statistical analysis was made using ANOVA with Tukey's test as post-test and $t$ test as appropriate. $\mathrm{n}$ denotes the number of different erythrocyte specimens studied. Since different erythrocyte specimens used in distinct experiments are differently susceptible to triggers of eryptosis, the same erythrocyte specimens have been used for control and experimental conditions.

\section{Results}

The present study explored the capacity of boswellic acid to stimulate suicidal erythrocyte death or eryptosis. Hallmarks of eryptosis include cell membrane scrambling with phosphatidylserine translocation to the cell surface. Phosphatidylserine at the erythrocyte surface was quantified utilizing annexin-V-binding, as determined by flow cytometry. The erythrocytes were analysed following incubation for 24 hours in Ringer solution without or with boswellic acid $(0.5-5 \mu \mathrm{g} / \mathrm{ml})$. As illustrated in Fig. 1B, a 24 hours exposure to 0.5 and $1 \mu \mathrm{g} / \mathrm{ml}$ did not significantly modify annexin-V-binding. However, incubation with $5 \mu \mathrm{g} / \mathrm{ml}$ boswellic acid significantly increased the percentage of annexin-V-binding erythrocytes.

In order to quantify hemolysis, the hemoglobin concentration in the supernatant was determined by photometry. As shown in Fig, 1B, a 24 hours incubation with boswellic acid (0.5 $-5 \mu \mathrm{g} / \mathrm{ml})$ did not significantly modify hemolysis.

\section{KARGER}



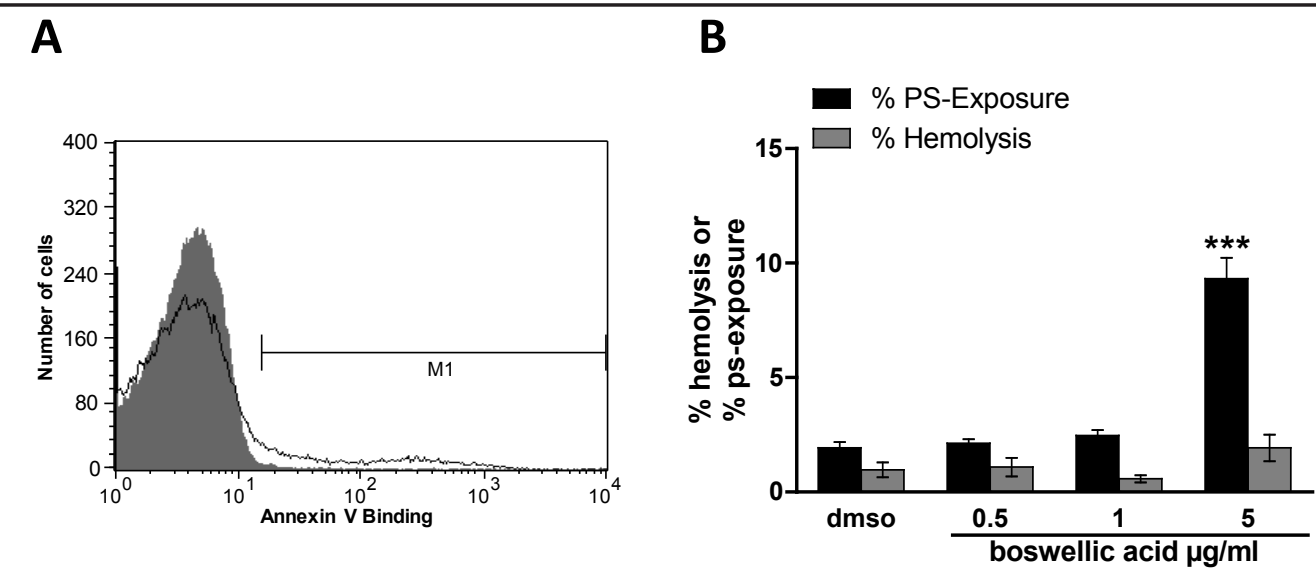

Fig. 1. Effect of boswellic acid on phosphatidylserine exposure. A. Original histogram of annexin-V-binding of erythrocytes following exposure for 24 hours to Ringer solution without (grey area) and with (black line) presence of $5 \mu \mathrm{g} / \mathrm{ml}$ boswellic acid. B. Arithmetic means \pm SEM $(\mathrm{n}=8)$ of erythrocyte annexin-V-binding (black bars) following incubation for 24 hours to Ringer solution without or with presence of boswellic acid $(0.5-5 \mu \mathrm{g} / \mathrm{ml})$. For comparison, the effect of boswellic acid on hemolysis is shown (grey bars). ${ }^{* * *}(\mathrm{p}<0.001)$ indicate significant difference from the absence of boswellic acid (ANOVA).

A

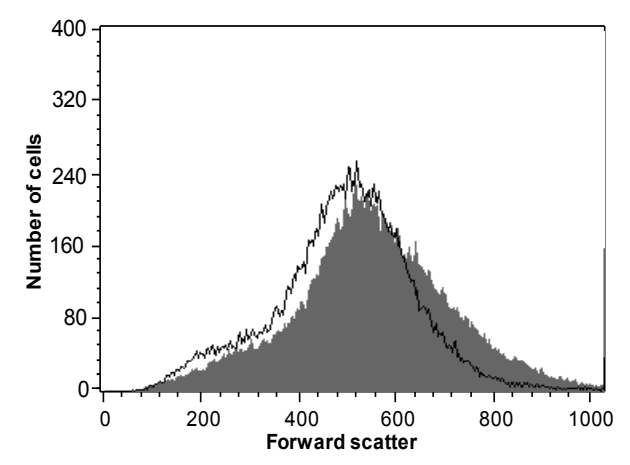

B

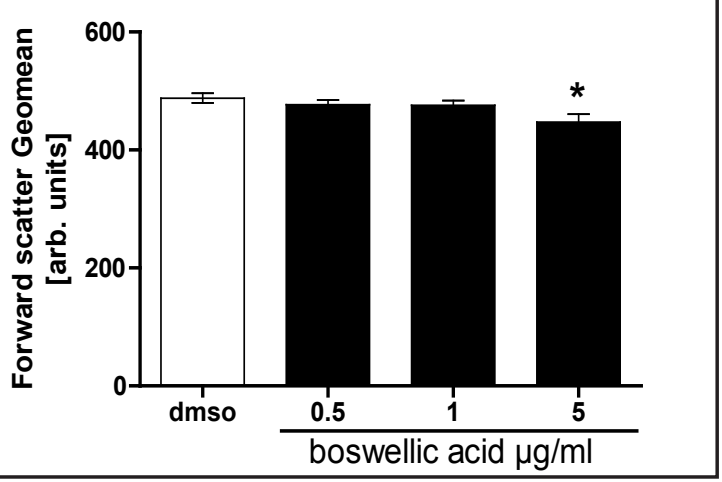

Fig. 2. Effect of boswellic acid on erythrocyte forward scatter. A. Original histogram of forward scatter of erythrocytes following exposure for 24 hours to Ringer solution without (grey area) and with (black line) presence of $5 \mu \mathrm{g} / \mathrm{ml}$ boswellic acid. B. Arithmetic means \pm SEM $(\mathrm{n}=8)$ of the erythrocyte forward scatter (FSC) following incubation for 24 hours to Ringer solution without (white bar) or with (black bars) boswellic acid $(0.5-5 \mu \mathrm{g} / \mathrm{ml}){ }^{*}(\mathrm{p}<0.05)$ indicate significant difference from the absence of boswellic acid (ANOVA).

The second hallmark of eryptosis is cell shrinkage. In order to estimate cell volume, forward scatter was determined utilizing flow cytometry following a 24 hours incubation in Ringer solution without or with boswellic acid $(0.5-5 \mu \mathrm{g} / \mathrm{ml})$. As shown in Fig, 2B, boswellic acid decreased erythrocyte forward scatter, an effect reaching statistical significance at $5 \mu \mathrm{g} /$ $\mathrm{ml}$ boswellic acid concentration.

In order to determine whether boswellic acid modifies cytosolic $\mathrm{Ca}^{2+}$ activity $\left(\left[\mathrm{Ca}^{2+}\right]_{\mathrm{i}}\right)$, Fluo3 fluorescence was taken as measure of $\left[\mathrm{Ca}^{2+}\right]_{\mathrm{i}}$. As a result, the Fluo3 fluorescence was similar following a 24 hours incubation without (23.3 \pm 1.0 a.u., $\mathrm{n}=8)$ and with $0.5 \mu \mathrm{g} /$ $\mathrm{ml}(23.2 \pm 1.0$ a.u., $\mathrm{n}=8) 1 \mu \mathrm{g} / \mathrm{ml}(23.2 \pm 1.0$ a.u., $\mathrm{n}=8)$ and $5 \mu \mathrm{g} / \mathrm{ml}(24.5 \pm 0.9$ a.u., $\mathrm{n}=$ 8) boswellic acid $(0.5-10 \mu \mathrm{g} / \mathrm{ml})$. Accordingly, boswellic acid did not significantly modify $\left[\mathrm{Ca}^{2+}\right]_{\mathrm{i}^{*}}$

Stimulators of eryptosis in the absence of increased $\left[\mathrm{Ca}^{2+}\right]_{\mathrm{i}}$ include ceramide. Thus, specific antibodies were utilized to quantify ceramide abundance at the erythrocyte surface. 


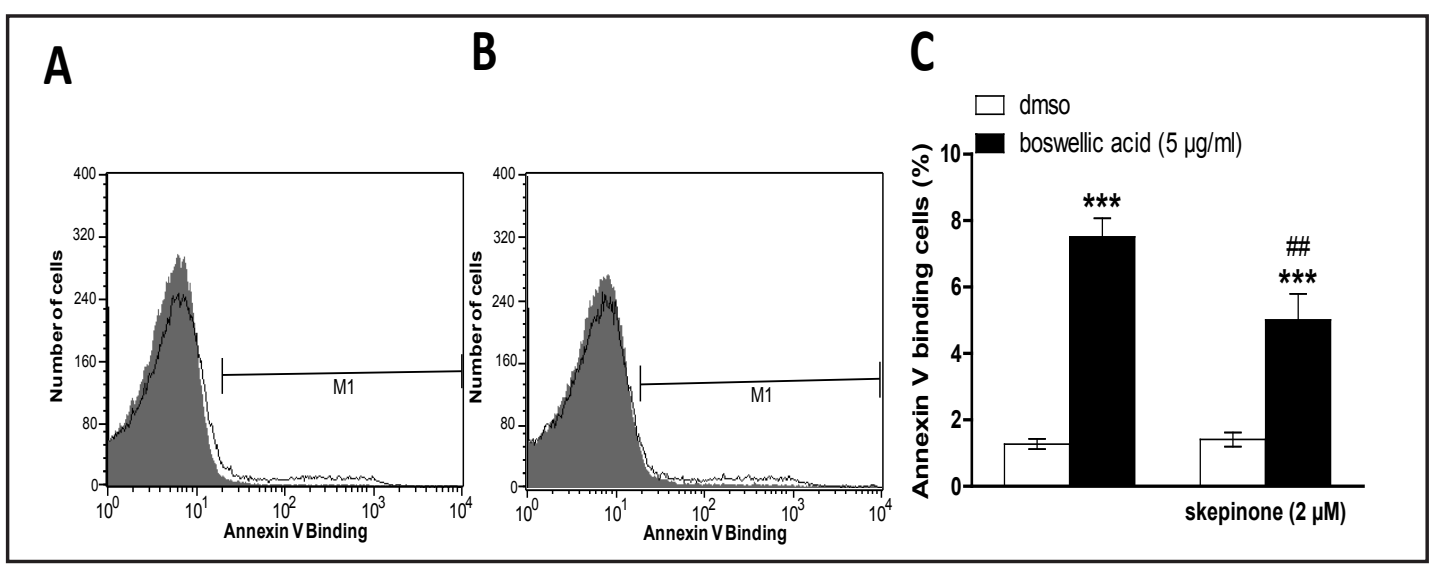

Fig. 3. Effect of boswellic acid on phosphatidylserine exposure in absence and presence of p38 kinase inhibitor skepinone. A,B. Original histogram of annexin-V-binding of erythrocytes following exposure for 24 hours to Ringer solution in the absence (A) and presence (B) of $5 \mu \mathrm{g} / \mathrm{ml}$ boswellic acid and with (grey area) and without (black line) presence of p38 kinase inhibitor skepinone $(2 \mu \mathrm{M})$. C. Arithmetic means \pm SEM of erythrocyte annexin-V-binding $(n=8)$ following incubation for 24 hours to Ringer solution without (white bars) or with (black bars) presence of boswellic acid $(5 \mu \mathrm{g} / \mathrm{ml}$ ) in the absence (left bars) and presence (right bars) of skepinone $(2 \mu \mathrm{M})$. *** $(\mathrm{p}<0.001)$ indicate significant difference from the absence of boswellic acid, \#\# $(\mathrm{p}<0.01)$ indicate significant difference from the absence of skepinone (ANOVA).

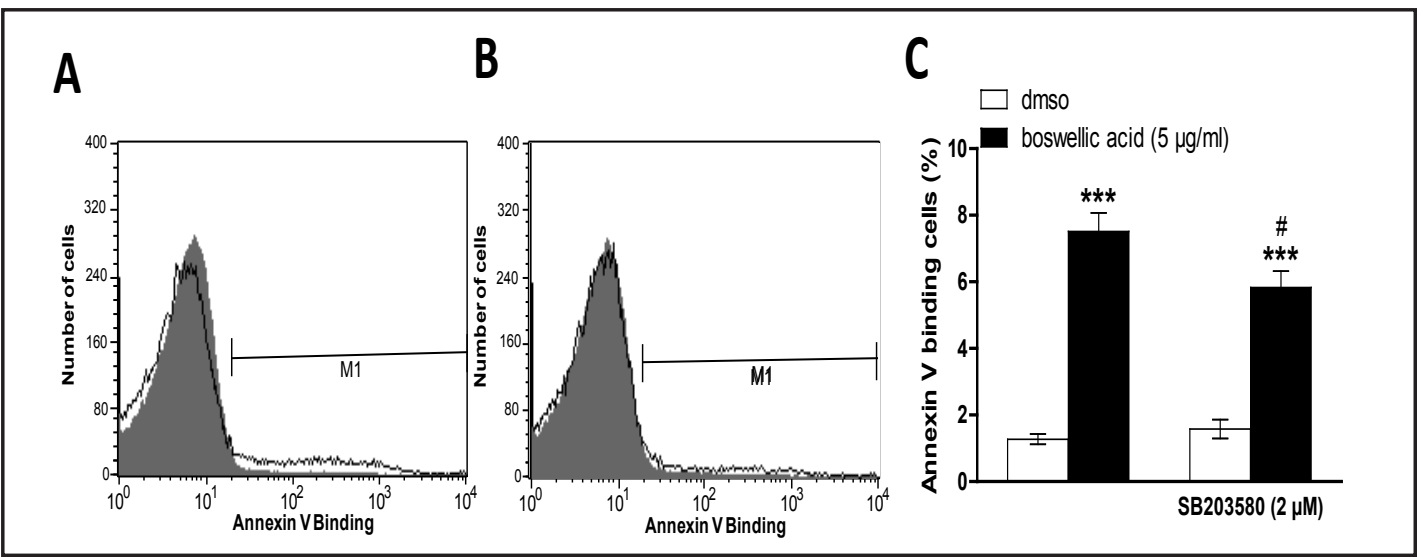

Fig. 4. Effect of boswellic acid on phosphatidylserine exposure in absence and presence of p38 kinase inhibitor SB203580. A,B. Original histogram of annexin-V-binding of erythrocytes following exposure for 24 hours to Ringer solution in the absence (A) and presence (B) of $5 \mu \mathrm{g} / \mathrm{ml}$ boswellic acid and with (grey area) and without (black line) presence of p38 kinase inhibitor SB203580 $(2 \mu \mathrm{M})$. C. Arithmetic means \pm SEM of erythrocyte annexin-V-binding $(n=8)$ following incubation for 24 hours to Ringer solution without (white bars) or with (black bars) presence of boswellic acid $(5 \mu \mathrm{g} / \mathrm{ml})$ in the absence (left bars) and presence (right bars) of SB203580 $(2 \mu \mathrm{M})$. *** $(\mathrm{p}<0.001)$ indicate significant difference from the absence of boswellic acid, \# $(\mathrm{p}<0.05)$ indicate significant difference from the absence of SB203580 (ANOVA).

As a result, the ceramide abundance was similar following a 24 hours incubation in the absence (16.5 \pm 1.9 a.u., $\mathrm{n}=8$ ) and presence (15.6 \pm 1.7 a.u., $\mathrm{n}=8)$ of $5 \mu \mathrm{g} / \mathrm{ml}$ boswellic acid.

Triggers of eryptosis include oxidative stress. Reactive oxygen species (ROS) was thus quantified utilizing $2^{\prime}, 7^{\prime}$-dichlorodihydrofluorescein diacetate (DCFDA). As a result, the DCFDA fluorescence was similar following a 24 hours incubation in the absence $(13.1 \pm 1.2$ a.u., $\mathrm{n}=8$ ) and presence (12.0 \pm 1.1 a.u., $\mathrm{n}=8$ ) of $5 \mu \mathrm{g} / \mathrm{ml}$ boswellic acid.

Eryptosis is further stimulated by energy depletion. A luciferin-luciferase assay was employed to determine the cytosolic ATP level. As a result, the cytosolic ATP concentration KARGER 


\section{Cellular Physiology Cell Physiol Biochem 2015;37:131-142 \begin{tabular}{l|l|l}
\hline DOI: 10.1159/000430339 2015 S. Karger AG, Basel & (C)
\end{tabular} and BiOChemistry Published online: August 17, $2015 \quad$ www.karger.com/cpb \\ Calabrò/Alzoubi/Faggio/Laufer/Lang: Boswellic Acid-Induced Eryptosis}

was similar following a 24 hours incubation in the absence $(2.3 \pm 0.4 \mathrm{mM}, \mathrm{n}=8)$ and presence $(1.9 \pm 0.2 \mathrm{mM}, \mathrm{n}=8)$ of $5 \mu \mathrm{g} / \mathrm{ml}$ boswellic acid.

Additional experiments explored whether boswellic acid-induced cell membrane scrambling was dependent on activation of p38 kinase. To this end, erythrocytes were exposed for 24 hours to $10 \mu \mathrm{g} / \mathrm{ml}$ boswellic acid in the absence or presence of the selective [83] p38 kinase inhibitor skepinone $(2 \mu \mathrm{M})$ or selective [84] p38 kinase inhibitor SB203580 $(2 \mu \mathrm{M})$. As a result, the effect of boswellic acid on annexin-V-binding was significantly blunted in the presence of p38 kinase inhibitors skepinone (Fig. 3) and SB203580 (Fig. 4).

\section{Discussion}

The present observations reveal a novel effect of boswellic acid, i.e. the stimulation of suicidal erythrocyte death or eryptosis. Exposure of human erythrocytes to boswellic acid is followed by the appearance of the two hallmarks of eryptosis, i.e. cell shrinkage and cell membrane scrambling with phosphatidylserine translocation to the erythrocyte surface. The boswellic acid concentration $(5 \mu \mathrm{g} / \mathrm{ml})$ required for stimulation of erythrocyte cell membrane scrambling was within the range of concentrations observed in vivo [85] and those required for stimulation of tumor cell apoptosis in vitro [25].

The effect of boswellic acid on cell membrane scrambling and cell shrinkage was apparently not due to increase of cytosolic $\mathrm{Ca}^{2+}$ activity $\left(\left[\mathrm{Ca}^{2+}\right]_{\mathrm{i}}\right)$. An increase of $\left[\mathrm{Ca}^{2+}\right]_{\mathrm{i}}$ accounts for the stimulation of cell membrane scrambling following treatment with a wide variety of xenobiotics [50]. An increase of $\left[\mathrm{Ca}^{2+}\right]_{\mathrm{i}}$ further activates $\mathrm{Ca}^{2+}$ sensitive $\mathrm{K}^{+}$channels with subsequent cell shrinkage due to $\mathrm{K}^{+}$exit, cell membrane hyperpolarization, $\mathrm{Cl}^{-}$exit and thus cellular loss of $\mathrm{KCl}$ with water [49]. Even though the observations do not exclude minor alterations of $\left[\mathrm{Ca}^{2+}\right]_{i^{\prime}}$ the strong effect of boswellic acid on cell membrane scrambling would require sizable increases of $\left[\mathrm{Ca}^{2+}\right]_{\mathrm{i}}[50]$.

The stimulation of cell membrane scrambling was further not paralleled by appreciable increases of reactive oxygen species (ROS), energy depletion or ceramide abundance at the cell surface. ROS, energy depletion and ceramide are well known triggers of eryptosis [50].

The boswellic acid induced eryptosis was significantly blunted by p38 kinase inhibitors skepinone and SB203580. Activation of p38 protein kinase has previously been shown to participate in the signaling of eryptosis [50].

Stimulation of eryptosis may be beneficial, as it allows disposal of defective erythrocytes prior to hemolysis [50]. Eryptosis thus prevents release of hemoglobin, which would be filtered in renal glomerula, precipitate in the acidic lumen of renal tubules and thus occlude nephrons [86]. Removal of eryptotic cells may further favourably influence the clinical course of malaria [87]. The malaria pathogen Plasmodium imposes oxidative stress on the infected host erythrocyte thus activating several host cell ion channels including $\mathrm{Ca}^{2+}$-permeable erythrocyte cation channels $[50,88]$. The stimulation of eryptosis by $\mathrm{Ca}^{2+}$ entry through those channels leads to subsequent clearance of infected erythrocytes from circulating blood [87]. By increasing the erythrocyte susceptibility to triggers of eryptosis, sickle-cell trait, beta-thalassemia-trait, $\mathrm{Hb}-\mathrm{C}$ and G6PD-deficiency protect against a severe course of malaria [50, 89-91]. Iron deficiency [92], and treatment with lead [92], chlorpromazine [93] or NO synthase inhibitors [93] similarly counteract parasitemia by increasing the erythrocyte susceptibility to triggers of eryptosis. It is tempting to speculate that boswellic acid may similarly foster eryptosis in plasmodium infected erythrocytes.

On the other hand, boswellic acid may aggravate anaema in clinical conditions associated with enhanced eryptosis, such as dehydration [70], hyperphosphatemia [81] chronic kidney disease (CKD) [59, 94-96], Hemolytic-uremic syndrome [97], diabetes [98], liver failure [99], malignancy [100], sepsis [101] and Wilsons disease [102]. Enhanced eryptosis with clearance of phosphatidylserine exposing erythrocytes from circulating blood leads to anemia, as soon as the loss of erythrocytes outcasts the generation of new erythrocytes [50]. Eryptotic erythrocytes may further adhere to the vascular wall [103], trigger blood clotting 


\section{Cellular Physiology Cell Physiol Biochem 2015;37:131-142 \begin{tabular}{|c|l|}
\hline DOI: 10.1159/000430339 & O 2015 S. Karger AG, Basel \\
\hline
\end{tabular} \begin{tabular}{l|l} 
and Biochemistry Published online: August 17, 2015 & www.karger.com/cpb
\end{tabular} \\ Calabrò/Alzoubi/Faggio/Laufer/Lang: Boswellic Acid-Induced Eryptosis}

and elicit thrombosis [104-106]. Eryptotic erythrocytes may thus impair microcirculation $[51,104,107-110]$.

In conclusion, boswellic acid triggers eryptosis with cell shrinkage and cell membrane scrambling, an effect paralleled by and in part due to activation of p38 protein kinase.

\section{Acknowledgements}

The authors acknowledge the meticulous preparation of the manuscript by Tanja Loch. The study was supported by the Deutsche Forschungsgemeinschaft and Open Access Publishing Fund of Tuebingen University.

\section{Disclosure Statement}

The authors declare no conflict of interest.

\section{References}

1 Ammon HP: Modulation of the immune system by Boswellia serrata extracts and boswellic acids. Phytomedicine 2010;17:862-867.

2 Moussaieff A, Mechoulam R: Boswellia resin: from religious ceremonies to medical uses; a review of invitro, in-vivo and clinical trials. J Pharm Pharmacol 2009;61:1281-1293.

3 Abdel-Tawab M, Werz O, Schubert-Zsilavecz M: Boswellia serrata: an overall assessment of in vitro, preclinical, pharmacokinetic and clinical data. Clin Pharmacokinet 2011;50:349-369.

4 Gautam R, Jachak SM: Recent developments in anti-inflammatory natural products. Med Res Rev 2009;29:767-820.

5 Ravanan P, Singh SK, Rao GS, Kondaiah P: Growth inhibitory, apoptotic and anti-inflammatory activities displayed by a novel modified triterpenoid, cyano enone of methyl boswellates. J Biosci 2011;36:297-307.

6 Recio MC, Andujar I, Rios JL: Anti-inflammatory agents from plants: progress and potential. Curr Med Chem 2012;19:2088-2103.

7 Shah BA, Qazi GN, Taneja SC: Boswellic acids: a group of medicinally important compounds. Nat Prod Rep 2009;26:72-89.

8 Yadav VR, Prasad S, Sung B, Kannappan R, Aggarwal BB: Targeting inflammatory pathways by triterpenoids for prevention and treatment of cancer. Toxins (Basel) 2010;2:2428-2466.

9 Agrawal SS, Saraswati S, Mathur R, Pandey M: Antitumor properties of Boswellic acid against Ehrlich ascites cells bearing mouse. Food Chem Toxicol 2011;49:1924-1934.

10 Chashoo G, Singh SK, Mondhe DM, Sharma PR, Andotra SS, Shah BA, Taneja SC, Saxena AK: Potentiation of the antitumor effect of 11-keto-beta-boswellic acid by its 3-alpha-hexanoyloxy derivative. Eur J Pharmacol 2011;668:390-400.

11 Chashoo G, Singh SK, Sharma PR, Mondhe DM, Hamid A, Saxena A, Andotra SS, Shah BA, Qazi NA, Taneja SC, Saxena AK: A propionyloxy derivative of 11-keto-beta-boswellic acid induces apoptosis in HL-60 cells mediated through topoisomerase I \& II inhibition. Chem Biol Interact 2011;189:60-71.

12 Liu HP, Gao ZH, Cui SX, Wang Y, Li BY, Lou HX, Qu XJ: Chemoprevention of intestinal adenomatous polyposis by acetyl-11-keto-beta-boswellic acid in APC(Min/+) mice. Int J Cancer 2013;132:2667-2681.

13 Safe SH, Prather PL, Brents LK, Chadalapaka G, Jutooru I: Unifying mechanisms of action of the anticancer activities of triterpenoids and synthetic analogs. Anticancer Agents Med Chem 2012;12:1211-1220.

14 Sankpal UT, Goodison S, Abdelrahim M, Basha R: Targeting Sp1 transcription factors in prostate cancer therapy. Med Chem 2011;7:518-525.

15 Wang R, Wang Y, Gao Z, Qu X: The comparative study of acetyl-11-keto-beta-boswellic acid (AKBA) and aspirin in the prevention of intestinal adenomatous polyposis in APC(Min/+) mice. Drug Discov Ther 2014;8:25-32. 


\section{Cellular Physiology Cell Physiol Biochem 2015;37:131-142 \begin{tabular}{l|l|l} 
DOI: 10.1159/000430339 & (C) 2015 S. Karger AG, Basel
\end{tabular} and Biochemistry Published online: August 17, 2015 \\ Calabrò/Alzoubi/Faggio/Laufer/Lang: Boswellic Acid-Induced Eryptosis}

16 Winking M, Sarikaya S, Rahmanian A, Jodicke A, Boker DK: Boswellic acids inhibit glioma growth: a new treatment option? J Neurooncol 2000;46:97-103.

17 Yadav VR, Prasad S, Sung B, Gelovani JG, Guha S, Krishnan S, Aggarwal BB: Boswellic acid inhibits growth and metastasis of human colorectal cancer in orthotopic mouse model by downregulating inflammatory, proliferative, invasive and angiogenic biomarkers. Int J Cancer 2012;130:2176-2184.

18 Buchele B, Zugmaier W, Estrada A, Genze F, Syrovets T, Paetz C, Schneider B, Simmet T: Characterization of 3alpha-acetyl-11-keto-alpha-boswellic acid, a pentacyclic triterpenoid inducing apoptosis in vitro and in vivo. Planta Med 2006;72:1285-1289.

19 Glaser T, Winter S, Groscurth P, Safayhi H, Sailer ER, Ammon HP, Schabet M, Weller M: Boswellic acids and malignant glioma: induction of apoptosis but no modulation of drug sensitivity. Br J Cancer 1999;80:756765.

20 Hostanska K, Daum G, Saller R: Cytostatic and apoptosis-inducing activity of boswellic acids toward malignant cell lines in vitro. Anticancer Res 2002;22:2853-2862.

21 Jing Y, Nakajo S, Xia L, Nakaya K, Fang Q Waxman S, Han R: Boswellic acid acetate induces differentiation and apoptosis in leukemia cell lines. Leuk Res 1999;23:43-50.

22 Kaur R, Khan S, Chib R, Kaur T, Sharma PR, Singh J, Shah BA, Taneja SC: A comparative study of proapoptotic potential of cyano analogues of boswellic acid and 11-keto-boswellic acid. Eur J Med Chem 2011;46:1356-1366.

23 Khan MA, Singh M, Khan MS, Najmi AK, Ahmad S: Caspase mediated synergistic effect of Boswellia serrata extract in combination with doxorubicin against human hepatocellular carcinoma. Biomed Res Int 2014;2014:294143.

24 Liu JJ, Duan RD: LY294002 enhances boswellic acid-induced apoptosis in colon cancer cells. Anticancer Res 2009;29:2987-2991.

25 Lu M, Xia L, Hua H, Jing Y: Acetyl-keto-beta-boswellic acid induces apoptosis through a death receptor 5-mediated pathway in prostate cancer cells. Cancer Res 2008;68:1180-1186.

26 Shah BA, Kumar A, Gupta P, Sharma M, Sethi VK, Saxena AK, Singh J, Qazi GN, Taneja SC: Cytotoxic and apoptotic activities of novel amino analogues of boswellic acids. Bioorg Med Chem Lett 2007;17:64116416.

27 Yuan Y, Cui SX, Wang Y, Ke HN, Wang RQ, Lou HX, Gao ZH, Qu XJ: Acetyl-11-keto-beta-boswellic acid (AKBA) prevents human colonic adenocarcinoma growth through modulation of multiple signaling pathways. Biochim Biophys Acta 2013;1830:4907-4916.

28 Zhao W, Entschladen F, Liu H, Niggemann B, Fang Q Zaenker KS, Han R: Boswellic acid acetate induces differentiation and apoptosis in highly metastatic melanoma and fibrosarcoma cells. Cancer Detect Prev 2003;27:67-75.

29 Khan S, Kaur R, Shah BA, Malik F, Kumar A, Bhushan S, Jain SK, Taneja SC, Singh J: A novel cyano derivative of 11-keto-beta-boswellic acid causes apoptotic death by disrupting PI3K/AKT/Hsp-90 cascade, mitochondrial integrity, and other cell survival signaling events in HL-60 cells. Mol Carcinog 2012;51:679695.

30 Park YS, Lee JH, Harwalkar JA, Bondar J, Safayhi H, Golubic M: Acetyl-11-keto-beta-boswellic acid (AKBA) is cytotoxic for meningioma cells and inhibits phosphorylation of the extracellular-signal regulated kinase 1 and 2. Adv Exp Med Biol 2002;507:387-393.

31 Pathania AS, Joshi A, Kumar S, Guru SK, Bhushan S, Sharma PR, Bhat WW, Saxena AK, Singh J, Shah BA, Andotra SS, Taneja SC, Malik FA, Kumar A: Reversal of boswellic acid analog BA145 induced caspase dependent apoptosis by PI3K inhibitor LY294002 and MEK inhibitor PD98059. Apoptosis 2013;18:15611573.

32 Zhang YS, Xie JZ, Zhong JL, Li YY, Wang RQ, Qin YZ, Lou HX, Gao ZH, Qu XJ: Acetyl-11-keto-beta-boswellic acid (AKBA) inhibits human gastric carcinoma growth through modulation of the Wnt/beta-catenin signaling pathway. Biochim Biophys Acta 2013;1830:3604-3615.

33 Khan S, Chib R, Shah BA, Wani ZA, Dhar N, Mondhe DM, Lattoo S, Jain SK, Taneja SC, Singh J: A cyano analogue of boswellic acid induces crosstalk between p53/PUMA/Bax and telomerase that stages the human papillomavirus type 18 positive HeLa cells to apoptotic death. Eur J Pharmacol 2011;660:241-248.

34 Hoernlein RF, Orlikowsky T, Zehrer C, Niethammer D, Sailer ER, Simmet T, Dannecker GE, Ammon HP: Acetyl-11-keto-beta-boswellic acid induces apoptosis in HL-60 and CCRF-CEM cells and inhibits topoisomerase I. J Pharmacol Exp Ther 1999;288:613-619. 


\section{Cellular Physiology Cell Physiol Biochem 2015;37:131-142 \begin{tabular}{l|l|l} 
DOI: 10.1159/000430339 & (C) 2015 S. Karger AG, Basel
\end{tabular} and Biochemistry Published online: August 17, 2015 \\ Calabrò/Alzoubi/Faggio/Laufer/Lang: Boswellic Acid-Induced Eryptosis}

35 Morad SA, Schmid M, Buchele B, Siehl HU, El Gafaary M, Lunov O, Syrovets T, Simmet T: A novel semisynthetic inhibitor of the FRB domain of mammalian target of rapamycin blocks proliferation and triggers apoptosis in chemoresistant prostate cancer cells. Mol Pharmacol 2013;83:531-541.

36 Park B, Prasad S, Yadav V, Sung B, Aggarwal BB: Boswellic acid suppresses growth and metastasis of human pancreatic tumors in an orthotopic nude mouse model through modulation of multiple targets. PLoS One 2011;6:e26943.

37 Qurishi Y, Hamid A, Sharma PR, Wani ZA, Mondhe DM, Singh SK, Zargar MA, Andotra SS, Shah BA, Taneja SC, Saxena AK: NF-kappaB down-regulation and PARP cleavage by novel 3-alpha-butyryloxy-beta-boswellic acid results in cancer cell specific apoptosis and in vivo tumor regression. Anticancer Agents Med Chem 2013;13:777-790.

38 Syrovets T, Gschwend JE, Buchele B, Laumonnier Y, Zugmaier W, Genze F, Simmet T: Inhibition of IkappaB kinase activity by acetyl-boswellic acids promotes apoptosis in androgen-independent PC-3 prostate cancer cells in vitro and in vivo. J Biol Chem 2005;280:6170-6180.

39 Takada Y, Ichikawa H, Badmaev V, Aggarwal BB: Acetyl-11-keto-beta-boswellic acid potentiates apoptosis, inhibits invasion, and abolishes osteoclastogenesis by suppressing NF-kappa B and NF-kappa B-regulated gene expression. J Immunol 2006;176:3127-3140.

40 Kunnumakkara AB, Nair AS, Sung B, Pandey MK, Aggarwal BB: Boswellic acid blocks signal transducers and activators of transcription 3 signaling, proliferation, and survival of multiple myeloma via the protein tyrosine phosphatase SHP-1. Mol Cancer Res 2009;7:118-128.

41 Roy S, Khanna S, Shah H, Rink C, Phillips C, Preuss H, Subbaraju GV, Trimurtulu G, Krishnaraju AV, Bagchi M, Bagchi D, Sen CK: Human genome screen to identify the genetic basis of the anti-inflammatory effects of Boswellia in microvascular endothelial cells. DNA Cell Biol 2005;24:244-255.

42 Shen Y, Takahashi M, Byun HM, Link A, Sharma N, Balaguer F, Leung HC, Boland CR, Goel A: Boswellic acid induces epigenetic alterations by modulating DNA methylation in colorectal cancer cells. Cancer Biol Ther 2012;13:542-552.

43 Takahashi M, Sung B, Shen Y, Hur K, Link A, Boland CR, Aggarwal BB, Goel A: Boswellic acid exerts antitumor effects in colorectal cancer cells by modulating expression of the let-7 and miR-200 microRNA family. Carcinogenesis 2012;33:2441-2449.

44 Zhang Y, Duan RD: Boswellic acid inhibits expression of acid sphingomyelinase in intestinal cells. Lipids Health Dis 2009;8:51.

45 Qurishi Y, Hamid A, Sharma PR, Wani ZA, Mondhe DM, Singh SK, Zargar MA, Andotra SS, Shah BA, Taneja SC, Saxena AK: PARP cleavage and perturbance in mitochondrial membrane potential by 3-alphapropionyloxy-beta-boswellic acid results in cancer cell death and tumor regression in murine models. Future Oncol 2012;8:867-881.

46 Liu JJ, Nilsson A, Oredsson S, Badmaev V, Duan RD: Keto- and acetyl-keto-boswellic acids inhibit proliferation and induce apoptosis in Hep G2 cells via a caspase-8 dependent pathway. Int J Mol Med 2002;10:501-505.

47 Liu JJ, Nilsson A, Oredsson S, Badmaev V, Zhao WZ, Duan RD: Boswellic acids trigger apoptosis via a pathway dependent on caspase-8 activation but independent on Fas/Fas ligand interaction in colon cancer HT-29 cells. Carcinogenesis 2002;23:2087-2093.

48 Xia L, Chen D, Han R, Fang Q, Waxman S, Jing Y: Boswellic acid acetate induces apoptosis through caspasemediated pathways in myeloid leukemia cells. Mol Cancer Ther 2005;4:381-388.

49 Lang PA, Kaiser S, Myssina S, Wieder T, Lang F, Huber SM: Role of Ca2+-activated K+ channels in human erythrocyte apoptosis. Am J Physiol Cell Physiol 2003;285:C1553-C1560.

50 Lang E, Qadri SM, Lang F: Killing me softly - suicidal erythrocyte death. Int J Biochem Cell Biol 2012;44:1236-1243.

51 Abed M, Towhid ST, Mia S, Pakladok T, Alesutan I, Borst O, Gawaz M, Gulbins E, Lang F: Sphingomyelinaseinduced adhesion of eryptotic erythrocytes to endothelial cells. Am J Physiol Cell Physiol 2012;303:C991999.

52 Lau IP, Chen H, Wang J, Ong HC, Leung KC, Ho HP, Kong SK: In vitro effect of CTAB- and PEG-coated gold nanorods on the induction of eryptosis/erythroptosis in human erythrocytes. Nanotoxicology 2012;6:847856. 


\section{Cellular Physiology Cell Physiol Biochem 2015;37:131-142 \begin{tabular}{l|l|l} 
DOI: 10.1159/000430339 & (C) 2015 S. Karger AG, Basel
\end{tabular} and Biochemistry Published online: August 17, 2015 \\ Calabrò/Alzoubi/Faggio/Laufer/Lang: Boswellic Acid-Induced Eryptosis}

53 Maellaro E, Leoncini S, Moretti D, Del Bello B, Tanganelli I, De Felice C, Ciccoli L: Erythrocyte caspase-3 activation and oxidative imbalance in erythrocytes and in plasma of type 2 diabetic patients. Acta Diabetol 2013;50:489-495.

54 Jilani K, Qadri SM, Lang F: Geldanamycin-induced phosphatidylserine translocation in the erythrocyte membrane. Cell Physiol Biochem 2013;32:1600-1609.

55 Vota DM, Maltaneri RE, Wenker SD, Nesse AB, Vittori DC: Differential erythropoietin action upon cells induced to eryptosis by different agents. Cell Biochem Biophys 2013;65:145-157.

56 Zappulla D: Environmental stress, erythrocyte dysfunctions, inflammation, and the metabolic syndrome: adaptations to CO2 increases? J Cardiometab Syndr 2008;3:30-34.

57 Zbidah M, Lupescu A, Jilani K, Lang F: Stimulation of suicidal erythrocyte death by fumagillin. Basic Clin Pharmacol Toxicol 2013;112:346-351.

58 Abed M, Herrmann T, Alzoubi K, Pakladok T, Lang F: Tannic Acid induced suicidal erythrocyte death. Cell Physiol Biochem 2013;32:1106-1116.

59 Ahmed MS, Langer H, Abed M, Voelkl J, Lang F: The uremic toxin acrolein promotes suicidal erythrocyte death. Kidney Blood Press Res 2013;37:158-167.

60 Ghashghaeinia M, Cluitmans JC, Toulany M, Saki M, Koberle M, Lang E, Dreischer P, Biedermann T, Duszenko M, Lang F, Bosman GJ, Wieder T: Age Sensitivity of NFkappaB Abundance and Programmed Cell Death in Erythrocytes Induced by NFkappaB Inhibitors. Cell Physiol Biochem 2013;32:801-813.

61 Alzoubi K, Honisch S, Abed M, Lang F: Triggering of Suicidal Erythrocyte Death by Penta-O-galloyl-beta-dglucose. Toxins (Basel) 2014;6:54-65.

62 Jilani K, Lang F: Carmustine-induced phosphatidylserine translocation in the erythrocyte membrane. Toxins (Basel) 2013;5:703-716.

63 Jilani K, Enkel S, Bissinger R, Almilaji A, Abed M, Lang F: Fluoxetine induced suicidal erythrocyte death. Toxins (Basel) 2013;5:1230-1243.

64 Lupescu A, Bissinger R, Jilani K, Lang F: Triggering of suicidal erythrocyte death by celecoxib. Toxins (Basel) 2013;5:1543-1554.

65 Lupescu A, Jilani K, Zbidah M, Lang F: Patulin-induced suicidal erythrocyte death. Cell Physiol Biochem 2013;32:291-299.

66 Abed M, Zoubi KA, Theurer M, Lang F: Effect of dermaseptin on erythrocytes. Basic Clin Pharmacol Toxicol 2013;113:347-352.

67 Arnold M, Lang E, Modicano P, Bissinger R, Faggio C, Abed M, Lang F: Effect of nitazoxanide on erythrocytes. Basic Clin Pharmacol Toxicol 2014;114:421-426.

68 Oswald G, Alzoubi K, Abed M, Lang F: Stimulation of suicidal erythrocyte death by ribavirin. Basic Clin Pharmacol Toxicol 2014;114:311-317.

69 Bissinger R, Malik A, Jilani K, Lang F: Triggering of Erythrocyte Cell Membrane Scrambling by Salinomycin. Basic Clin Pharmacol Toxicol 2014;10.1111/bcpt.12250

70 Abed M, Feger M, Alzoubi K, Pakladok T, Frauenfeld L, Geiger C, Towhid ST, Lang F: Sensitization of erythrocytes to suicidal erythrocyte death following water deprivation. Kidney Blood Press Res 2013;37:567-578.

71 Alzoubi K, Calabròa S, Bissinger R, Abed M, Faggio C, Lang F: Stimulation of Suicidal Erythrocyte Death by Artesunate. Cell Physiol Biochem 2014;34:2232-2244.

72 Arnold M, Bissinger R, Lang F: Mitoxantrone-induced suicidal erythrocyte death. Cell Physiol Biochem 2014;34:1756-1767.

73 Bissinger R, Fischer S, Jilani K, Lang F: Stimulation of Erythrocyte Death by Phloretin. Cell Physiol Biochem 2014;34:2256-2265.

74 Bissinger R, Lupescu A, Zelenak C, Jilani K, Lang F: Stimulation of eryptosis by cryptotanshinone. Cell Physiol Biochem 2014;34:432-442.

75 Bissinger R, Modicano P, Frauenfeld L, Lang E, Jacobi J, Faggio C, Lang F: Estramustine-induced suicidal erythrocyte death. Cell Physiol Biochem 2013;32:1426-1436.

76 Jacobi J, Lang E, Bissinger R, Frauenfeld L, Modicano P, Faggio C, Abed M, Lang F: Stimulation of erythrocyte cell membrane scrambling by mitotane. Cell Physiol Biochem 2014;33:1516-1526.

77 Lupescu A, Bissinger R, Herrmann T, Oswald G, Jilani K, Lang F: Induction of suicidal erythrocyte death by novobiocin. Cell Physiol Biochem 2014;33:670-680. 


\section{Cellular Physiology Cell Physiol Biochem 2015;37:131-142 \begin{tabular}{l|l|l} 
DOI: 10.1159/000430339 & (C) 2015 S. Karger AG, Basel
\end{tabular} and Biochemistry Published online: August 17, 2015

78 Lupescu A, Bissinger R, Warsi J, Jilani K, Lang F: Stimulation of erythrocyte cell membrane scrambling by gedunin. Cell Physiol Biochem 2014;33:1838-1848.

79 Malik A, Bissinger R, Calabro S, Faggio C, Jilani K, Lang F: Aristolochic Acid Induced Suicidal Erythrocyte Death. Kidney Blood Press Res 2014;39:408-419.

80 Tesoriere L, Attanzio A, Allegra M, Cilla A, Gentile C, Livrea MA: Oxysterol mixture in hypercholesterolemiarelevant proportion causes oxidative stress-dependent eryptosis. Cell Physiol Biochem 2014;34:10751089.

81 Voelkl J, Alzoubi K, Mamar AK, Ahmed MS, Abed M, Lang F: Stimulation of suicidal erythrocyte death by increased extracellular phosphate concentrations. Kidney Blood Press Res 2013;38:42-51.

82 Zhang R, Xiang Y, Ran Q, Deng X, Xiao Y, Xiang L, Li Z: Involvement of calcium, reactive oxygen species, and ATP in hexavalent chromium-induced damage in red blood cells. Cell Physiol Biochem 2014;34:1780-1791.

83 Koeberle SC, Romir J, Fischer S, Koeberle A, Schattel V, Albrecht W, Grutter C, Werz O, Rauh D, Stehle T, Laufer SA: Skepinone-L is a selective p38 mitogen-activated protein kinase inhibitor. Nat Chem Biol 2012;8:141-143.

84 Lim SJ, Lee YJ, Lee E: p38MAPK inhibitor SB203580 sensitizes human SNU-C4 colon cancer cells to exisulind-induced apoptosis. Oncol Rep 2006;16:1131-1135.

85 Gerbeth K, Meins J, Kirste S, Momm F, Schubert-Zsilavecz M, Abdel-Tawab M: Determination of major boswellic acids in plasma by high-pressure liquid chromatography/mass spectrometry. J Pharm Biomed Anal 2011;56:998-1005.

86 Harrison HE, Bunting H, Ordway NK, Albrink WS: The Pathogenesis of the Renal Injury Produced in the Dog by Hemoglobin or Methemoglobin. J Exp Med 1947;86:339-356.

87 Foller M, Bobbala D, Koka S, Huber SM, Gulbins E, Lang F: Suicide for survival--death of infected erythrocytes as a host mechanism to survive malaria. Cell Physiol Biochem 2009;24:133-140.

88 Kirk K: Membrane transport in the malaria-infected erythrocyte. Physiol Rev 2001;81:495-537.

89 Ayi K, Giribaldi G, Skorokhod A, Schwarzer E, Prendergast PT, Arese P: 16alpha-bromoepiandrosterone, an antimalarial analogue of the hormone dehydroepiandrosterone, enhances phagocytosis of ring stage parasitized erythrocytes: a novel mechanism for antimalarial activity. Antimicrob Agents Chemother 2002;46:3180-3184.

90 Ayi K, Turrini F, Piga A, Arese P: Enhanced phagocytosis of ring-parasitized mutant erythrocytes: a common mechanism that may explain protection against falciparum malaria in sickle trait and beta-thalassemia trait. Blood 2004;104:3364-3371.

91 Cappadoro M, Giribaldi G, O'Brien E, Turrini F, Mannu F, Ulliers D, Simula G, Luzzatto L, Arese P: Early phagocytosis of glucose-6-phosphate dehydrogenase (G6PD)-deficient erythrocytes parasitized by Plasmodium falciparum may explain malaria protection in G6PD deficiency. Blood 1998;92:2527-2534.

92 Koka S, Huber SM, Boini KM, Lang C, Foller M, Lang F: Lead decreases parasitemia and enhances survival of Plasmodium berghei-infected mice. Biochem Biophys Res Commun 2007;363:484-489.

93 Koka S, Lang C, Niemoeller OM, Boini KM, Nicolay JP, Huber SM, Lang F: Influence of NO synthase inhibitor L-NAME on parasitemia and survival of Plasmodium berghei infected mice. Cell Physiol Biochem 2008;21:481-488.

94 Abed M, Artunc F, Alzoubi K, Honisch S, Baumann D, Foller M, Lang F: Suicidal erythrocyte death in endstage renal disease. J Mol Med (Berl) 2014;92:871-879.

95 Calderon-Salinas JV, Munoz-Reyes EG, Guerrero-Romero JF, Rodriguez-Moran M, Bracho-Riquelme RL, Carrera-Gracia MA, Quintanar-Escorza MA: Eryptosis and oxidative damage in type 2 diabetic mellitus patients with chronic kidney disease. Mol Cell Biochem 2011;357:171-179.

96 Polak-Jonkisz D, Purzyc L: Ca(2+) influx versus efflux during eryptosis in uremic erythrocytes. Blood Purif 2012;34:209-210; author reply 210.

97 Lang PA, Beringer O, Nicolay JP, Amon O, Kempe DS, Hermle T, Attanasio P, Akel A, Schafer R, Friedrich B, Risler T, Baur M, Olbricht CJ, Zimmerhackl LB, Zipfel PF, Wieder T, Lang F: Suicidal death of erythrocytes in recurrent hemolytic uremic syndrome. J Mol Med (Berl) 2006;84:378-388.

98 Nicolay JP, Schneider J, Niemoeller OM, Artunc F, Portero-Otin M, Haik G, Jr., Thornalley PJ, Schleicher E, Wieder T, Lang F: Stimulation of suicidal erythrocyte death by methylglyoxal. Cell Physiol Biochem 2006;18:223-232. 


\section{Cellular Physiology Cell Physiol Biochem 2015;37:131-142 \begin{tabular}{ll|l} 
and Biochemistry & $\begin{array}{l}\text { DOI: 10.1159/000430339 } \\
\text { Published online: August 17, 2015 }\end{array}$ & $\begin{array}{l}\text { O 2015 S. Karger AG, Basel } \\
\text { www.karger.com/cpb }\end{array}$ \\
\cline { 2 - 3 }
\end{tabular} \\ Calabrò/Alzoubi/Faggio/Laufer/Lang: Boswellic Acid-Induced Eryptosis}

99 Lang E, Gatidis S, Freise NF, Bock H, Kubitz R, Lauermann C, Orth HM, Klindt C, Schuier M, Keitel V, Reich M, Liu G, Schmidt S, Xu HC, Qadri SM, Herebian D, Pandyra AA, Mayatepek E, Gulbins E, Lang F, Haussinger D, Lang KS, Foller M, Lang PA: Conjugated bilirubin triggers anemia by inducing erythrocyte death. Hepatology 2015;61:275-284.

100 Qadri SM, Mahmud H, Lang E, Gu S, Bobbala D, Zelenak C, Jilani K, Siegfried A, Foller M, Lang F: Enhanced suicidal erythrocyte death in mice carrying a loss-of-function mutation of the adenomatous polyposis coli gene. J Cell Mol Med 2012;16:1085-1093.

101 Kempe DS, Akel A, Lang PA, Hermle T, Biswas R, Muresanu J, Friedrich B, Dreischer P, Wolz C, Schumacher U, Peschel A, Gotz F, Doring G, Wieder T, Gulbins E, Lang F: Suicidal erythrocyte death in sepsis. J Mol Med (Berl) 2007;85:273-281.

102 Lang PA, Schenck M, Nicolay JP, Becker JU, Kempe DS, Lupescu A, Koka S, Eisele K, Klarl BA, Rubben H, Schmid KW, Mann K, Hildenbrand S, Hefter H, Huber SM, Wieder T, Erhardt A, Haussinger D, Gulbins E, Lang F: Liver cell death and anemia in Wilson disease involve acid sphingomyelinase and ceramide. Nat Med 2007;13:164-170.

103 Borst O, Abed M, Alesutan I, Towhid ST, Qadri SM, Foller M, Gawaz M, Lang F: Dynamic adhesion of eryptotic erythrocytes to endothelial cells via CXCL16/SR-PSOX. Am J Physiol Cell Physiol 2012;302:C644-C651.

104 Andrews DA, Low PS: Role of red blood cells in thrombosis. Curr Opin Hematol 1999;6:76-82.

105 Chung SM, Bae ON, Lim KM, Noh JY, Lee MY, Jung YS, Chung JH: Lysophosphatidic acid induces thrombogenic activity through phosphatidylserine exposure and procoagulant microvesicle generation in human erythrocytes. Arterioscler Thromb Vasc Biol 2007;27:414-421.

106 Zwaal RF, Comfurius P, Bevers EM: Surface exposure of phosphatidylserine in pathological cells. Cell Mol Life Sci 2005;62:971-988.

107 Closse C, Dachary-Prigent J, Boisseau MR: Phosphatidylserine-related adhesion of human erythrocytes to vascular endothelium. Br J Haematol 1999;107:300-302.

108 Gallagher PG, Chang SH, Rettig MP, Neely JE, Hillery CA, Smith BD, Low PS: Altered erythrocyte endothelial adherence and membrane phospholipid asymmetry in hereditary hydrocytosis. Blood 2003;101:46254627.

109 Pandolfi A, Di Pietro N, Sirolli V, Giardinelli A, Di Silvestre S, Amoroso L, Di Tomo P, Capani F, Consoli A, Bonomini M: Mechanisms of uremic erythrocyte-induced adhesion of human monocytes to cultured endothelial cells. J Cell Physiol 2007;213:699-709.

110 Wood BL, Gibson DF, Tait JF: Increased erythrocyte phosphatidylserine exposure in sickle cell disease: flowcytometric measurement and clinical associations. Blood 1996;88:1873-1880. 